\title{
Mesurer sa respiration. Reconstituer le corps avec un objet médical
}

Dick Willems

\section{(2) OpenEdition \\ 12 Journals}

Édition électronique

URL : https://journals.openedition.org/tc/504

DOI : $10.4000 /$ tc. 504

ISSN : 1952-420X

Éditeur

Éditions de l'EHESS

\section{Édition imprimée}

Date de publication : 1 mars 1996

ISSN : 0248-6016

\section{Référence électronique}

Dick Willems, « Mesurer sa respiration. Reconstituer le corps avec un objet médical », Techniques \& Culture [En ligne], 25-26 | 1996, mis en ligne le 28 octobre 2005, consulté le 29 septembre 2022. URL http://journals.openedition.org/tc/504 ; DOI : https://doi.org/10.4000/tc.504

Ce document a été généré automatiquement le 29 septembre 2022.

Tous droits réservés 


\section{Mesurer sa respiration. Reconstituer le corps avec un objet médical}

Dick Willems 